Departamento de Historia Universidad de Santiago de Chile

Revista de Historia Social y de las Mentalidades

Volumen 25, $\mathrm{N}^{\circ} 2,2021: 43-66$

Issn Online: 0719-4749

\title{
LA PRODUCCIÓN MEDIÁTICA DE "LOS POBRES DE LA CIUDAD”: EL CASO DE LA SERIE TELEVISIVA RAMONA*
}

\author{
THE MEDIA PRODUCTION OF "THE IMPOVERISHED INHABITANTS OF THE CITY": \\ A CASE STUDY OF RAMONA TV SERIES
}

\author{
EDUARDO SANTA CRUZ A.** \\ Universidad de Chile \\ Santiago, Chile \\ Email: esantacruz@uchile.cl \\ Id-ORCID: 0000-0002-6166-9985
}
DRA. CLAUDIA LAGOS LIRA Universidad de Chile
Santiago, Chile
Email: cllagos@uchile.cl
Id-ORCID: 000-0003-2557-5401

\begin{abstract}
RESUMEN
Este texto analiza la representación audiovisual de los llamados "pobres de la ciudad" en su desarrollo como movimiento social, específicamente a partir de la serie televisiva

Ramona exhibida por la televisión pública chilena en 2017 y 2018. La producción sitúa su narración en 1967 y ofrece una lectura diversa y compleja que contribuye a sedimentar un cierto sentido común audiovisual y una memoria colectiva mediática sobre el período
\end{abstract}

\begin{abstract}
This article provides a close reading of the visual portrayals about "the impoverished inhabitants of the city" as a social movement. It does so by analyzing Ramona, a fiction television series broadcast by the Chilean public television in 2017 and 2018. The story is set in 1967 and it depicts a complex overview fueling what we call a visual common sense and a certain media social memory about both the historical period and the phenomenon Ramona illustrates. The
\end{abstract}

** Este artículo es parte de la investigación "Sello América Latina de exportación de la ficción televisiva: Mercado, comunicación y experiencia en la era del streaming”, con investigadores de Brasil, Colombia, México y Chile. El equipo chileno está integrado por Lorena Antezana, Consuelo Ábalos y Cristian Cabello, además de los autores de este artículo. 
y el fenómeno que representa. La producción mediática de "los pobres de la ciudad" es más que centenaria y se ha expresado en diversos lenguajes, géneros, formatos y artefactos culturales, que han instalado en el sentido común masivo interpretaciones de un fenómeno central en la historia chilena, y con la cual Ramona dialoga pero, también, abre otras claves representacionales y mediáticas.

Palabras clave: Historia social chilena; cultura de masas; televisión chilena; series televisivas media production about "the impoverished inhabitants of the city" is more than one hundred years old and a plurality of languages, genres, styles, and cultural artifacts have represented it. Books, cartoons, films, or radio programming have promoted readings of popular characters, lives, and processes that have been key to Chilean history and a part of a cultural common sense, too. Ramona follows those previous paths at the same time it opens new media and interpretative clues.

Keywords: Chilean Social History; Mass Culture; Chilean Television; Television Series

Cómo citar: Santa Cruz, Eduardo y Claudia Lagos L. (2021). "La producción mediática de "los pobres de la ciudad": El caso de la serie televisiva Ramona". Revista Historia Social y de las Mentalidades, 25(2), 43-66. https://doi.org/10.35588/rhsm.v25i2.4904

\section{PRESENTACIÓN}

Ramona (Wood, TVN, CNTV, 2017-2018) es analizada como un estudio de caso de producción de ficción televisiva ambientada en un período histórico específico. A partir de una lectura detallada de la serie, discutimos las articulaciones entre las estrategias de producción, sus características seriales, su televisualidad y cómo estas dimensiones producen discursos sobre lo popular y la historia social y política de la segunda mitad del siglo XX en Chile. En efecto, la ficción televisiva es significativa, ya que recoge y amplía la tradición de la narración oral, pues:

Sin representar ni deformar propiamente la realidad, las historias narradas por televisión más bien la reescriben y la comentan, ocupando un lugar preeminente en las esferas de las 'prácticas interpretativas' mediante las cuales en cada época los hombres han creado sus propias visiones y versiones del mundo y han dado sentido a la vida cotidiana. (Buonano 62)

Así, la televisión opera como un actor socio-cultural, contextual e históricamente situado y que asume cada vez más un aspecto multifacético orientado a su transformación en plataformas mediáticas que combinan lenguajes, códigos, géneros y formatos, debido a, entre otros factores, cambios tecnológicos agudos. La discusión sobre Ramona se ubica en un análisis intertextual a la vez 
que audiovisual de un artefacto cultural central para la producción y circulación de identidades, memorias e historia en las sociedades contemporáneas mediadas y mediatizadas.

Entre 2011 y 2020, la televisión chilena produjo y emitió 60 series de ficción. La mayoría (25), basadas en hechos históricos reales o ambientadas en épocas específicas de la historia chilena. La conmemoración en 2010 de los 200 años de la Independencia y, en 2013, de los 40 años desde el Golpe de Estado explicaría esta tendencia. Ambos hitos, en particular el de la independencia, movilizaron políticas, recursos y la acción de instituciones públicas y privadas en la construcción de la memoria e identidad colectivas, nacionales. La producción audiovisual masiva no fue la excepción.

Este fenómeno de carácter nacional dialoga con tendencias regionales y locales de lo audiovisual, incluyendo la emergencia y consolidación de producción de ficción en televisión por cable, primero, y en plataformas de streaming, luego. Esto ha modificado las formas de consumir televisión en un escenario globalizado competitivo.

Ramona es una serie de televisión de doce capítulos ambientada en el Chile de 1967 que relata la historia de dos hermanas, Ramona, la mayor (interpretada por Giannina Fruttero) y Helga (interpretada por Belén Herrera). Tras la muerte de la madre, ambas jóvenes deciden abandonar su pueblo natal de Santa Bárbara, en el sur de Chile, determinadas a alejarse de un padre abusador, alcohólico y de una existencia marcada por la pobreza rural. Al llegar a la capital como polizonas en tren, Ramona y Helga solo encuentran cabida en una toma de terrenos al borde de un río donde se encuentran y forman familia con Carmen (Paola Lattus). Así, la marginalidad social y la cotidianidad de la vida de los "pobres de la ciudad" pasan a ser la materialidad sobre la cual el discurso de la serie construye el sentido que nos propone. ${ }^{1}$

1 Realizada por Wood Producciones, escrita por Guillermo Calderón (dramaturgo; guionista de Araña, de Wood; Ema, Neruda y El club, de Larraín) y dirigida por Andrés Wood (Machuca, Violeta se fue a los cielos y Araña, entre otras), Julio Jorquera y Marcos Sánchez, Ramona costó más de \$513 millones aportados por el Consejo Nacional de Televisión (CNTV), fondo concursable público chileno que fomenta la realización audiovisual. Las grabaciones finalizaron en octubre de 2015, pero TVN la emitió dos años después (del 28 de octubre del 2017 al 21 de enero de 2018). Ramona fue bien recibida por la crítica y obtuvo varios premios. En streaming, está disponible en Movistar Play y estuvo en All Arts, plataforma creada por WNET New York Public Media, la compañía madre de las estaciones neoyorkinas del Public Broadcasting System (PBS), cadena de estaciones públicas estadounidenses. Como toda producción financiada por el CNTV, Ramona está disponible en play.cntv.cl. 


\section{EL "MUNDO REAL" DE RAMONA}

"Las ocupaciones ilegales de terrenos son casi tan antiguas como la ciudad misma" (De Ramón 245). Ya desde mediados del siglo XIX se constatan en Chile flujos migratorios desde el campo a las ciudades. En efecto, varias ciudades del país experimentaron una creciente aglomeración de personas provenientes de zonas rurales que se asentaron en los bordes de la ciudad. En esos rancheríos levantados en los bordes urbanos, el "peonaje femenino" (Salazar, Labradores) ocupaba un lugar importante. Desde la periferia, los plebeyos y plebeyas se desplazaban hacia el centro de las ciudades a ofrecer sus servicios en distintos ámbitos o a vender en la calle, gatillando escándalo y temor en la oligarquía (L.A. Romero). Esta colisión no pasó inadvertida por la prensa. El Ferrocarril, un diario liberal moderado (Santa Cruz, La prensa chilena 71-106), editorializó recurrentemente sobre la miseria:

Nuestra riqueza se desarrolla con increíble rapidez. La opulencia va ostentando por todas partes sus fascinaciones; ya es casi una orgía de palacios, de carruajes, de mármoles, de bronces, de cuadros, de tapices. Mientras tanto, las clases trabajadoras quedan a la puerta en estas harturas de la prosperidad. Para ellas es el reverso de la medalla (...) Santiago estará aún más estrechado y más amenazado por las hordas de los hambrientos, que son la nueva invasión de los bárbaros que castiga a todas las civilizaciones imprevisoras. (El Ferrocarril, "La transformación de los barrios pobres", 28 abril 1872) ${ }^{2}$

En el contexto de la "cuestión social", a fines del siglo XIX e inicios del XX, los más pobres habitaron diversos tipos de viviendas: el "rancho" de la periferia, cercano a corrientes de agua (como el Zanjón de la Aguada, en la capital) o el "conventillo" en el interior de la ciudad, cerca del centro. En un contexto de hacinamiento, falta de ventilación y poco acceso a agua potable y alcantarillado, miles murieron por epidemias (Vial Correa). ${ }^{3}$ Frente a estas condiciones de sobrevivencia de vastos sectores de la población, sectores de la elite política y social y de la Iglesia Católica impulsaron iniciativas paliativas para un problema que era de habitación, pero también de salubridad e higiene.

2 Ver también editoriales 3, 5 y 14 de mayo; 16 y 18 de junio; 13, 17 y 20 de julio y 14 de agosto de 1872.

3 A pesar de una alta natalidad (36 al 39\%), la tasa de crecimiento de la población era baja (1.1\% en 1910), debido a una elevada tasa de mortalidad, especialmente en niños. En 1921, la mortalidad llegó al 32.7\% y Vial Correa se refirió a Chile como "el país de los muertos". 
En ese contexto, se dictó la Ley de Habitaciones Obreras (1906); ${ }^{4}$ la primera Ley de la Vivienda (1925) y se creó la Caja de la Habitación Popular (1936, reestructurada en 1943), organismo que impulsó planes de construcción de vivienda. Las Cajas de Previsión Social, en tanto, emprendieron iniciativas similares. Sin embargo, este tipo de acciones excluían a la mayor parte de los "pobres de la ciudad", cuyo número aumentaba en condiciones extremas de pobreza. ${ }^{5}$ La migración se intensificó: Santiago, por ejemplo, casi triplicó su población entre 1930 y 1960 debido a la migración campo-ciudad y al desplazamiento de obreros del salitre desempleados tras la decadencia de esa industria a inicios del siglo XX. Se configuraba en el país, no solo en la capital, lo que José Luis Romero llama "la ciudad de masas".

El proceso de masificación y crecimiento - muchas veces caótico- de las ciudades se produjo en la sociedad latinoamericana, en general: Las tomas de terrenos o barrios de invasión parecían ser la forma en que esa masa plebeya enfrentaba la búsqueda de un lugar donde vivir y, también, incorporarse a esa modernización:

A la dispersión que implicaban las invasiones de la periferia por los pobres $(. .$.$) respondían los ricos alejándose hacia otra periferia. Y la$ masa siguió invadiendo todo. Porque en medio de su ignorancia de las normas, y del desafío que su sola presencia entrañaba, su deseo más secreto era acceder a los bienes que representaba la ciudad. Las masas querían trabajo, salud, educación y diversión. Pero no podían reivindicar su derecho a esos bienes sin masificarlo todo (...) la masificación ponía al descubierto su paradoja: era en la integración donde anidaba la subversión. (Martin-Barbero 172)

En 1952, el 30\% de las viviendas en Chile eran precarias (el 36.2\%, en la capital). En Santiago, se contaban 41 "poblaciones callampas", con 35.611 habitantes. ${ }^{6}$ Durante la década de 1950 surgen los Comités Sin Casa como forma

4 Esta iniciativa tuvo un fuerte impulso en el "higienismo", corriente que enfatizaba la influencia del entorno ambiental y del medio social en las enfermedades. En 1892 se creó el Consejo Superior de Higiene Pública, que comenzó en Chile el desarrollo de políticas de salud pública y vacunación masiva.

5 La noción de "pobres de la ciudad" fue usada en Chile en la segunda mitad del siglo XX por movimientos políticos de izquierda para referirse a sectores populares masivos, provenientes de la migración campo-ciudad, más amplios y heterogéneos que el proletariado organizado.

6 Estas personas recibieron el calificativo peyorativo de "callamperos", sinónimo de ignorante, sucio y eventual delincuente. El Zanjón de la Aguada era la más conocida y emblemática de estas 
de organización social y el epíteto de "pobladores" sustituye paulatinamente al de "callamperos" y amplía las filas del movimiento popular organizado (Garcés, Tomando su sitio; Espinoza). La masificación creaba condiciones para visibilizar lo popular. Durante esta década se vuelven habituales las tomas de terrenos como estrategia para proveerse una vivienda, de otra manera inaccesible (Salazar, Violencia política).

El gobierno demócrata cristiano de Eduardo Frei Montalva enfrentó el problema de la vivienda incorporando las dimensiones del equipamiento y de la organización social. Se elaboró una "teoría de la marginalidad" para comprender la situación que mantiene a familias o comunidades marginadas. Esa administración creó, también, la Consejería Nacional de Promoción Popular e impulsó la promulgación de la Ley de Juntas de Vecinos y Organizaciones Comunitarias (1968), instrumentos que contribuyeron a fundar miles de Juntas de Vecinos y Centros de Madres en el país.

La serie de televisión Ramona transcurre durante esos años en que la historia contemporánea chilena registra un intenso movimiento social de lucha de los pobladores por acceder a la vivienda, utilizando la toma de terrenos como herramienta fundamental. Así, Ramona construye un discurso desde el cual emerge un sentido audiovisual que apela a la memoria colectiva para recrear un periodo significativo de la historia social y política chilenas durante la segunda mitad del siglo XX, con sus claroscuros (materiales y simbólicos).

\section{EL CAMPO CULTURAL Y LA REPRESENTACIÓN DE LO POPULAR}

\section{De la palabra (o la literatura de lo popular)}

La construcción discursiva de la industria cultural chilena acerca de la representación de la estructura social proviene, en primer lugar, del campo literario, del Realismo, movimiento que se extendió desde mediados del siglo XIX hasta pasado $1950 .^{7}$ Alberto Blest Gana y Luis Orrego Luco son las dos

poblaciones callampa y ocupaba una franja de cinco kilómetros, en dirección oriente/poniente, desde Vicuña Mackenna a la actual Avenida General Velásquez, por la ribera de ese curso de agua. Tenía unos 125 metros de ancho y llegó a albergar diez poblaciones, con unas 35.000 personas. Existía un pilón de agua por cada 1.500 habitantes y una letrina por 500 usuarios. En octubre de 1957 se produjeron dos incendios masivos que empujaron a unas dos mil familias a ocupar los terrenos de la Chacra La Feria, originando la Población La Victoria. El apoyo del Cardenal Caro y dirigentes socialistas y comunistas impidieron el desalojo.

7 Cfr. www.memoriachilena.cl. Minisitio: "Realismo. Una visión permanente en la literatura chilena". 
figuras centrales que encarnan dicha corriente. De esta, derivaron otras, como el Costumbrismo, el Naturalismo y el Criollismo. Este último reivindica personajes, historias y costumbres del campo chileno y Mariano Latorre es su principal exponente (Latcham, et al.).

A comienzos del siglo XX se generó el Realismo Crítico o Social. Con la publicación de Subterra (1906) y Subsole (1907), Baldomero Lillo es considerado el "padre" de esta corriente. Es la época en que estalla "la cuestión social" (Garcés, Crisis social; Silva Castro, Baldomero Lillo) y emergen poetas como José Domingo Gómez Rojas, muerto en la cárcel acusado de subversivo en 1920, o Carlos Pezoa Véliz (Subercaseaux).

Esta corriente se expresará, luego, en lo que se conoce como Generación del 38, según algunos, o del 42, según otros. ${ }^{8}$ Entre los autores de dicha tradición destaca un grupo apegado a un realismo con sentido social y político, como Nicomedes Guzmán, especialmente con La sangre y la esperanza (1943), cuya historia transcurre a comienzos del siglo XX en el mundo popular urbano y en una familia proletaria; o como Andrés Sabella, "el poeta de la pampa", con su novela Norte Grande o la historia del salitre (1959); o Francisco Coloane (Cabo de Hornos, 1941; El último grumete de la Baquedano, 1941). Volodia Teitelboim (Hijo del Salitre, 1952) y Baltazar Castro (Mi camarada padre, 1958) se inscriben en esta vertiente cultural de y sobre el pueblo, el sujeto popular y la cuestión social. Estos autores tienden a privilegiar como protagonistas a personajes provenientes de la clase obrera organizada. ${ }^{9}$ Luis Merino Reyes, en tanto, convierte a la "clase media" en la protagonista de sus cuentos y novelas, con personajes principales femeninos (Matriarcado, 1965).

La crítica considera que Manuel Rojas (1896-1973) "revolucionó la forma narrativa, rechazando al realismo tradicional del naturalismo y el criollismo" (Memoria Chilena, Minisitio: "Manuel Rojas") e introdujo en la narración el monólogo interior o "corriente de la conciencia". Para efectos de este trabajo, Rojas es relevante por su "inserción sicológica y existencial en sus personajes, situados en una condición de marginalidad social" (Memoria Chilena, Minisitio: "Manuel Rojas"). Autodidacta, su obra tiene un fuerte componente autobiográfico. Rojas también publicó en Ecran, a principios de los años 1940, artículos sobre la relación entre el cine y el teatro.

Hacia mediados del siglo XX, surge lo que se conoce como literatura de bajos fondos, que agrupa obras que abordan un "submundo marginal, donde

8 Cfr. www.memoriachilena.cl. Minisitio: "Generación literaria de 1938".

9 A excepción de Coloane, que ubica sus historias en el extremo austral de Chile. 
sedimenta todo aquello que la sociedad considerapeligrosoy decadente. Constituye el reino miserable del hampa" (Memoria Chilena, Minisitio: "Literatura de bajos fondos"). Los autores de esta corriente, a su vez, se ubicaban en los márgenes del campo literario, algunos provenientes de los mismos ambientes que pretenden retratar. Otros, lograrían un relativo reconocimiento.

Entre ellos se cuenta Armando Méndez Carrasco y su personaje Juan Firula, que creó para su primer libro de cuentos y seudónimo con el que firmó sus crónicas en Las Últimas Noticias. Méndez publicó, entre otras, Chicago Chico (1962, novela que tuvo 15 ediciones) y Diccionario Coa (1979). Luis Cornejo Gamboa, en tanto, vendía sus libros autoeditados (como Barrio Bravo, 1955; Los amantes de London Park, 1960 o El último lunes, 1986, entre otros) en la calle, hasta su muerte en 1992. Además, fue actor y participó en algunas películas. El autor de bajos fondos de mayor éxito de ventas y con mayor repercusión mediática fue Alfredo Gómez Morel: creció bajo los puentes del río Mapocho, fue delincuente y estuvo un tiempo preso. Precisamente en la cárcel comenzó a escribir su novela más importante, El Río (1962). Obra autobiográfica, fue traducida al francés y publicada por la editorial Gallimard, en París, con un prólogo de Pablo Neruda, quien la definió como "un clásico de la miseria" (Memoria Chilena, Minisitio: "Literatura de bajos fondos"). Por último, mientras aún era funcionario de Carabineros, la policía militarizada chilena, Luis Rivano publicó Esto no es el paraíso (1965). La novela ilustra la vida de los policías y sus relaciones con el hampa, lo que le costó a Rivano la expulsión de la institución, pero también una relativa fama literaria que después acrecentó como dramaturgo.

\section{De la imagen (o el cine de lo popular)}

Si analizamos otros sectores del campo cultural, como el cine chileno, el volumen de obras sobre la marginalidad social o que retraten la vida y personajes del mundo popular urbano es menor en comparación a la rica tradición literaria enunciada. En la época del cine silente hay registro del film Uno de abajo (1920), un drama social de conventillos que retrata el desalojo de residentes debido a deudas de alquiler. No obstante, a inicios de ese siglo hay, más bien, filmes que pueden ser catalogados como de costumbrismo campesino, propios de la matriz conservadora nacionalista (Larraín). Este tipo de producciones se desarrolla ampliamente en la década de 1940, al calor del modelo industrializador, la migración campo-ciudad y el crecimiento de las ciudades, justamente para hacer el contrapunto en favor de una vida rural supuestamente más auténtica que la vida cotidiana urbana. 
En la década de los años 1940 irrumpen unos personajes que encarnan a tipos populares urbanos que podrían clasificarse en alguna vertiente del criollismo o costumbrismo pero en clave de comedia y que son representados en diversos lenguajes y soportes. Juan Verdejo parte como una caricatura en una revista satírico-política, Topaze, encarnando al pueblo chileno frente a la clase política; sigue en radio, en un radioteatro cómico (Intimidades de la familia Verdejo) y pasa al cine, con una película muy exitosa en términos de taquilla (Verdejo gasta un millón), y otra no tanto (Verdejo gobierna en Villaflor) (M. Salinas et al.). En tanto, el actor que lo encarnó en el cine, Eugenio Retes, desarrolló un estilo de actuación, un estereotipo de lo popular, con personajes de distintos nombres incluidos en varias otras películas de José Bohr, director también de las anteriores.

Perejil fue la contrapartida más marginal a Verdejo y, además, alcohólico. Creado por el dibujante Lugoze, se publicó durante décadas como tira cómica en El Mercurio. La caricatura Condorito, en tanto, surgió por primera vez en 1949, protagonizando una película de dibujos animados, y ofreció un matiz interesante: remite a lo urbano popular, pero desprovisto de algunas de las características criticadas en los otros, como el alcoholismo.

Estos tres personajes son tributarios de Cantinflas, cuya primera película llegó a Chile en 1938. En otros países de la región también hubo personajes similares que representan a un tipo de personaje popular urbano que vive al borde de la legalidad, en los márgenes sociales y económicos, con permanentes conflictos con la ley. Sin embargo, encarnan lo popular en clave individual, desvinculados de organizaciones sociales o políticas (King 82-83).

Un cuarto personaje popular y urbano es femenino. Se trata de una empleada doméstica, la Desideria, interpretada por Ana González, quien también incursionó en el cine ( $P$ 'al otro lao y La dama de las Camelias, con Bohr como director), en el teatro $\mathrm{y}$, particularmente, en radio, como personaje cómico durante décadas; tantas, que le abrió camino para una larga carrera en televisión. La Desideria es la única de estos personajes que, a pesar de ser cómico, exhibe cierto desparpajo frente al patrón y al poder, reivindicando, por ejemplo, su pertenencia a un sindicato.

En los años 1940 hay una película poco conocida, Encrucijada (1947, dir. Patricio Kaulen,), un melodrama policial que transcurre en los cerros de Valparaíso, con un mundo marginal, miserable y delincuencial como escenario (Santa Cruz, "Cine y sociedad"). Más tarde, en el período del Nuevo Cine Chileno y a pesar de su explícito compromiso social y político, los filmes de ficción donde los sectores pobres de la ciudad aparecen como protagonistas o, al menos, como tema son escasos. Destacan Morir un Poco (1967, dir. Álvaro Covacevic), 
Largo Viaje (1967, dir. Patricio Kaulen) y Valparaíso, mi amor (1969, dir. Aldo Francia). El Chacal de Nahueltoro (1970, dir. Miguel Littin), en tanto, aborda la marginalidad rural y sus miserias humanas de consecuencias trágicas. En la posdictadura, en tanto,

la representación del sujeto popular en el cine chileno del período (1997-2005) es (...) descriptiva, (...) concibe lo popular como un conjunto de atributos naturalizados, tomados del sentido común, con altos grados de componentes humorísticos y sexuales. Esta representación se realiza mediante la identificación de lo popular con ciertos estereotipos preconocidos por los espectadores, expurgándoles todo elemento político explícito o constitutivo (Salinas y Stange 36).

En el discurso hegemónico del actual cambio de siglo, lo popular se manifiesta en los discursos mediáticos en dos direcciones: en un sentido plebeyo, es decir, como una sumatoria de grupos e individuos pobres y necesitados y en tanto masas consumidoras, como multitud que borra las clásicas distinciones entre sectores populares y medios. En la industria cultural, en general, y los medios, en particular, es posible detectar estereotipos que intentan cubrir dicho abigarrado conjunto. Uno muy importante es el del individuo o la familia popular, en tanto sujeto desvalido y sufriente. Las desigualdades y carencias reales permiten a los medios erguirse como voceros del sufrimiento popular en tanto drama individual, merecedor de caridad.

Una segunda forma en que lo popular aparece en los discursos hegemónicos de fines del siglo XX y principios del XXI establece cierta continuidad con la figura que emerge de la industria cultural del siglo XX. Lo cómico y picaresco, fundamentalmente en la televisión y el cine, recoge, a su vez, otros fragmentos, generalmente aquellos más vulgares. En años recientes se ha mostrado cierta comedia, carente de irreverencia ante el poder; más bien, una picaresca popular domesticada. Esta suerte de costumbrismo ha tenido versiones relativamente más elaboradas, como es el caso de El Chacotero Sentimental, basada en el programa radial del mismo nombre, y su secuela, Radio Corazón, o en la película Sexo con Amor.

Una tercera forma de manifestación de lo popular en el período está asociada a la amenaza y el temor. Sin embargo, ya no corresponde a la figura del roto alzado, organizado en sindicatos o militante. La figura actual encarna, más bien, una amenaza directa a los bienes y a las personas, pero sin una proyección que exceda el puro beneficio individual de los agresores. La televisión abierta 
exhibe la amenaza de la delincuencia sobre los barrios acomodados. Lo popular como amenaza aparece, también, ligado al narcotráfico y a las pandillas que controlan barrios. Esta figura amenazante se liga a la primera, pues una de sus víctimas es, también, los populares sufrientes. Desde la instalación del sistema democrático liberal representativo en 1990, la delincuencia y la seguridad fueron emergiendo en el discurso mediático como unos de los problemas centrales de la vida nacional (Guzmán y Ramos).

En el cine chileno reciente encontramos una variante de lo anterior en la representación de un actor popular marginal, cuya existencia oscila entre la delincuencia y el empleo informal e inestable. Esos relatos destacan una vida de carencias y abandono, de dificultades de acceso al mercado y la modernidad y una falta de sentidos que vayan más allá de satisfacer necesidades inmediatas. Varias películas se ubican en este registro: desde Caluga o Menta hasta Taxi para Tres y Mala Leche, pasando por Johnny Cien Pesos o La Fiebre del Loco. Los escasos intentos de caracterizar un sujeto popular colectivo activo y en lucha han sido en una clave histórica, filtrada por las necesidades de consolidación de las hegemonías actuales (Salinas y Stange). Solo la película Machuca, del mismo director de la serie de televisión Ramona, representa la marginalidad social provista de organización, tejido y proyecto colectivo. La obra da cuenta del periodo del gobierno de la Unidad Popular (UP, 1970-1973) como una época durante la cual se desarrolla una lucha de clases aguda. Así, los personajes de Machuca encarnan sujetos sociales colectivos en pugna.

La televisión, en tanto, registra en sus orígenes universitarios una serie que Canal 13 transmitió entre 1965 y 1966, una vez a la semana, con éxito de sintonía: El Litre 4916. Era un programa "cultural de contenidos", en un "formato típico de la cultura de masas: la serie argumental".

Estos son los 'héroes' o personajes protagónicos, incorporándose su lenguaje habitual, problemas y costumbres, en una perspectiva formativa (desde hábitos alimenticios hasta temas de organización social y relaciones familiares). Esta serie tuvo éxitos de audiencia e identificó a los receptores. Los actores que encarnaban a esta familia tuvieron gran popularidad. (Hurtado 175)

Posteriormente, lo popular urbano en la ficción televisiva estuvo fundamentalmente presente en las telenovelas que estandarizan su producción desde los años 1980 (Santa Cruz, Las telenovelas). Las representaciones de lo popular urbano en dichas producciones apelaban, en general, a personajes que reciclan el roto pícaro y una de sus variantes está en Amores de Mercado (TVN) 
con la incorporación de un personaje que es un delincuente, ha estado en la cárcel, maltrata a su mujer $\mathrm{y}$, sin embargo, tiene protagonismo en la historia. La telenovela Puertas Adentro (TVN) tematizó la toma de terrenos en relación directa a la "toma de Peñalolén", uno de los pocos casos de ese tipo de referencias durante la década de 1990.

La producción de series para televisión o para otras plataformas, desarrolladas y emitidas al inicio del presente siglo, renovaron el interés por la marginalidad y la pobreza urbana en tanto temas, más allá de los dramas individuales. Es el caso de series como La Cacería, El Reemplazante o Ramona.

\section{FICCIÓN AUDIOVISUAL E HISTORIA}

La televisión ejecuta una operación sistemática para crear efectos de sentido sobre la vida y la cultura cotidianas y establece una compleja relación con el sentido común. Así, el discurso televisivo no es discernible desde su pura inmanencia, sino que, más bien, a partir de la radical historicidad de toda estrategia comunicacional. De allí se comprende su vínculo con el sentido común. ${ }^{10}$

La ficción audiovisual ha recurrido al discurso histórico para generar textos visuales que intentan explicar el presente de la realidad social, combinando elementos del sentido común para dotar de verosimilitud a sus relatos. No se trata de una suerte de reconstrucción verdadera de los hechos históricos, sino que de una interpretación verosímil acerca de su significado.

Por "representación verosímil" de la ficción audiovisual, nos referimos a un "efecto de realidad" que se consigue mediante recursos discursivos y narrativos. Lo verosímil no es lo simplemente similar a su referente, sino que es lo habitual. Los criterios de verosimilitud en los que está fundada una representación audiovisual no son, obviamente, universales, naturales ni inmutables: están cruzados por el carácter (o espíritu) general de la época en que la obra es producida por los gustos, valores e imaginarios con que esa época

10 En tanto materialización masiva de una cierta visión de mundo, el sentido común es uno de los niveles en que se manifiesta la ideología. Su rasgo más fundamental es ser una concepción de mundo disgregada, incoherente e incongruente, conforme a la posición social y cultural de las multitudes, para los cuales constituye su única filosofía de vida. Se trata de una "filosofía espontánea", por oposición al nivel de la concepción de mundo elaborada y sistemática constituida por la "teoría". La noción de espontaneidad no se refiere a su originalidad, sino que a que es vivida y aplicada en lo cotidiano irreflexivamente, sin conciencia de sí misma. Dicho de otra forma, son fragmentos abigarrados y heteróclitos de explicación de la vida que asumen el carácter de lo natural, de aquello que no tendría ni necesitaría explicación, que es porque es (Gramsci). 
lee el pasado. En otras palabras, la forma fílmica se posa sobre un tejido de convenciones compartidas, tanto por los espectadores como por los productores o realizadores, un trasfondo discursivo y representacional que configura un sentido común audiovisual (C. Salinas et al.).

Una serie de ficción audiovisual puede entenderse como un discurso social, inserto en un sistema productivo (Rodrigo-Alsina). En ese proceso de construcción intervienen tres mundos: el mundo real, el mundo de referencia y el mundo posible. Así, el mundo real corresponde al de los acontecimientos; el mundo de referencia, a los modelos en los que se puede encuadrar el acontecimiento para ser comprendido y el mundo posible, al mundo construido. Si en el mundo real se produce la verificación y en el mundo de referencia se determina la verosimilitud, en el mundo posible se desarrolla la veridicción, es decir, el sentido transmitido se hace creíble. El producto audiovisual debe hacer parecer verdad el mundo posible que construye. A partir de estas vertientes teóricas es posible leer la serie de televisión, Ramona.

\section{MEMORIA E HISTORIA EN RAMONA}

Ramona ofrece un conjunto de planos discursivos rico y complejo acerca del pasado reciente de la sociedad chilena. Si bien hace referencia a procesos y fenómenos sociales e históricos, la serie lo hace en una clave narrativa cuyo elemento central es la reconstrucción de una cotidianidad.

Lo cotidiano es lo humilde y lo sólido, lo que se da por supuesto, aquello cuyas partes y fragmentos se encadenan en un empleo del tiempo. Y esto sin que uno (el interesado) tenga que examinar las articulaciones de esas partes. Es lo que no lleva fecha. Es lo insignificante (aparentemente); ocupa y preocupa y, sin embargo, no tiene necesidad de ser dicho. (Lefebvre 36-37)

Lo cotidiano es, también, aquello que caracteriza el material fundamental de una narrativa melodramática pues ésta se sitúa en el plano de una sociabilidad primordial, como es la del parentesco, de las solidaridades vecinales y de amistad:

Entre el tiempo de la historia -que es el tiempo de la nación y del mundo, el de los grandes acontecimientos que vienen a irrumpir en la comunidad- y el tiempo de la vida -que es el que va del nacimiento a la muerte de cada individuo y que jalonan los ritos que señalan el 
paso de una edad a otra-, el tiempo familiar es el que media y hace posible su comunicación. (Martín-Barbero y Muñoz 28).

Ramona concreta esta operación discursiva construyendo un mundo posible verosímil por la vía de colocar al centro la dura vida cotidiana de los "marginales" y apelando a un sentido común masivo, afincado en la vigencia de una memoria. Ortiz distingue entre memoria nacional y memoria colectiva (1997). La primera se refiere a una historia que trasciende los sujetos y no se concreta inmediatamente en sus cotidianidades; es del orden de la ideología y un producto de la historia social. Si bien, a veces, se ritualiza en fiestas que actualizan, por ejemplo, el mito de la fundación nacional, la memoria nacional es más bien construida por una instancia exterior a las conciencias individuales y es parte de una esfera de poder. Los mitos que la sostienen duran en tanto exista consenso social y político en torno a su veracidad. En ese sentido, remite al tiempo de la historia.

La memoria colectiva, en tanto, correspondería al orden de lo vivencial, un conjunto de recuerdos activados por el filtro del presente, constituyendo un patrimonio que, experimentado por un grupo de personas, se actualiza en cada momento de rememoración y que, para existir, debe encarnarse, materializarse. Sin ello, los recuerdos se pulverizarían.

\section{De las mujeres en Ramona}

Dado que las protagonistas de la serie son tres mujeres (Ramona, Helga y Carmen), hay una serie de alusiones a problemas y conflictos de género que intentan situarse en los contextos culturales y sociales de la época. En otras palabras, se citan mundos referenciales que resultan verosímiles. Ramona y su hermana huyendo de un padre abusador es, en cierto sentido, una cita a la realidad campesina representada también en el film El Chacal de Nahueltoro (Littin, 1970), basado en un hecho de sangre, real, ocurrido a principios de la década de 1960.

En Ramona, los problemas de género están presentes a lo largo de la narración, develando el rol subordinado de la mujer en el marco de una cotidianidad marginal. La visibilización de la marginalidad de las mujeres populares urbanas en clave de género se verifica en varios planos como, por ejemplo, en la amenaza permanente de violencia sexual, especialmente en el caso de la hermana menor, Helga.

La serie representa audiovisualmente cuáles serían los trabajos "aceptables" para la mujer popular en el contexto de marginalidad provocada por la migración 
campo-ciudad, particularmente trabajos domésticos externos como lavandera o, bien, como empleada de casa particular "puertas adentro". En este caso, la mujer urbana popular recorre parcial y relativamente otros circuitos sociales a los de su propia experiencia vital y lugar social. Otro camino posible para la inserción laboral de las mujeres populares, en la lectura de Ramona, es el de la prostitución $\mathrm{o}$, en un escalón previo, la mantención de locales "clandestinos" para vender alcohol ilegalmente. Estas experiencias de trabajo de las mujeres populares de la ciudad problematizadas por Ramona se vinculan a la noción de Salazar del "peonaje femenino" y a la realidad de mujeres del sector popular, vigente desde los "rancheríos" o conventillos de fines del siglo XIX y principios del XX.

En un plano secundario, Ramona hace referencia a otros "mundos femeninos" de la época, en particular con ciertos personajes, espacios y trayectorias vitales femeninas de clase media o acomodada. Una vía de conexión con ese mundo la encarna una joven y su madre, quienes calzan con cierto estereotipo de mujer blanca, relativamente frívola, pero "moderna" en el acceso a ciertas claves culturales, tecnológicas y materiales. Esos personajes calzan con la propuesta de Michelle Mattelart acerca de las revistas femeninas de la época en su versión más integrada, como $E v a$, u relativamente transgresora, como Paula (Montalva). No parece casual, entonces, la escena en que esta joven sostiene el primer número de Paula y se lo regala a Helga, la joven pobladora recién incorporada como personal doméstico.

Para Michelle Mattelart, las revistas ilustradas para la mujer, a mediados del siglo XX, difunden un modelo modernista universal, "construido sobre la base de un estereotipo de mujer de estrato socioeconómico muy acomodado en una sociedad industrializada de la esfera capitalista" (145). Mattelart agrega que "este modelo destaca eufóricamente la situación de dichas mujeres, exagera el bienestar, la liberación, el goce que alcanzan en la vida cotidiana" (145). Para la autora, el cambio en el estatus de la mujer en la segunda mitad del siglo XX se transformó en sinónimo de integración a la modernidad y la imagen de la mujer feliz, deslumbrada por el afán y la posibilidad de acceder al consumo y al progreso. Tal imagen de "mujer moderna", señala Michelle Mattelart, "no sobrepasa nunca los límites de adaptación al contexto, definida por la modernidad, lo cual significa nunca una agresión a los principios del sistema" (148). El acceso al estudio y al trabajo aparece como un agregado y no una ruptura del rol tradicional que provendría de la "naturaleza femenina". Así, lo tradicional cobra vigencia y se eterniza en lo moderno:

El núcleo de la teoría implícita sobre la liberación femenina que se cobija en este modelo consiste en rescatarla de la intimidad hogareña 
para lanzarla en un mundo exterior donde se individualiza y, por tanto, se libera gracias a una competencia basada en la adquisición de bienes y el acatamiento fervoroso de la moda. (Mattelart 150).

La serie exhibe como contraste brutal las condiciones y aspiraciones de estas mujeres de clase media acomodada y la realidad de sobrevivencia de la mujer pobladora a través de una forma narrativa y audiovisual que recuerda un tratamiento similar al de la película Machuca, del mismo Wood.

\section{De lo marginal y lo popular en Ramona}

La serie exhibe la cotidianidad de la marginalidad: la sobrevivencia es una demanda y se vive día a día. Dicha experiencia cotidiana de la marginalidad modela relaciones duras y directas, sin espacio para matices ni eufemismos. Dicho de otro modo, es el tiempo de la vida que les toca a los personajes y "contra" el cual se (sobre) vive. Sin embargo, no es solo la carencia y las dificultades económicas; lo marginal implica, más bien, un juego permanente de equilibrio en las orillas de lo permitido y donde todo es inestable e inseguro.

Ramona significa al mundo popular como un ambiente fundamentalmente machista y patriarcal, aunque la mujer juega un rol activo y, muchas veces, protagónico, motivado por las carencias y urgencias de una vida miserable. En esa representación está jugando un sentido común y una memoria, que ha naturalizado que la mujer asumiría enfrentar una cotidianidad adversa como constitutivo de su rol de género.

Resulta interesante la incorporación de un personaje homosexual (Memo), que es tolerado, aunque en un rol subordinado, y es objeto también de violencia física y simbólica. Vale recordar personajes "cómicos" en la época en que la serie está ambientada, presentes en radio (como el "Tereso", por ejemplo), que estereotipaban al hombre homosexual como un ser afeminado. En su mejor versión, incorporaba actitudes y valores "propios" de la mujer, como un "instinto" de protección y cuidado de los demás. Estos valores y actitudes se ven claramente personificadas en Ramona.

La serie logra reconstruir un cierto "modo de vida marginal" que resulta verosímil. Dicho "modo de vida marginal" incluye el alcoholismo y, por lo tanto, la existencia de clandestinos; la cotidianidad de la experiencia de abortos ilegales en condiciones de insalubridad y su censura por parte del entorno ilustrado (médicos y enfermeras); la existencia de niños abandonados que pasan a engrosar una categoría social de la época, "recogido" (como el niño 
Ossiel, cuya madre muere a consecuencia de un aborto clandestino en malas condiciones, y el de Manuel, pareja de Ramona); abusos sexuales y violencia contra las mujeres, jóvenes dedicados al delito y a diversas actividades ilegales (Sergio). Las actividades ligadas al tráfico o menudeo de drogas no aparecen en Ramona, pues como fenómeno delictual y su impacto social en campamentos y poblaciones es posterior a la época que recrea la serie.

A pesar de ese marco, se desarrollan historias románticas: amores sin mediaciones, directos; pero, a la vez, romances más complejos, articulados con un contexto de vida áspero y que movilizan claves de mayor realismo que las historias de amor con "final feliz". Son romances que funcionan (como el caso de Ramona y Manuel) o no (como el de Héctor y Carmen). Pueden ser relaciones más militantes que pasionales (compañeros antes que amantes, como Héctor y Elvira) o, bien, pueden ser relaciones marcadas por la tragedia (como la de Sergio y Helga).

\section{Del actor colectivo en Ramona}

La serie hace un contrapunto al mostrar cómo, frente a distintas contingencias, emergen redes de solidaridad y apoyo entre los vecinos, manteniendo vigentes prácticas sociales tradicionales. Asimismo, Ramona representa a la organización social y política como un espacio de crecimiento y superación personal y colectiva. Es significativa la apelación a la memoria colectiva popular en la figura de Luis Emilio Recabarren, como ícono que preside reuniones y conversaciones desde su retrato colgado en una pared de la mediagua, la postura crítica al alcoholismo y el rechazo a la violencia contra la mujer encarnado en ciertos personajes, discursos y escenas. Ramona, en efecto, incluye numerosas referencias a una tradición de organización popular y a la persistencia de una memoria de dichas prácticas. A través de referencias a hechos políticos del momento en que se ambienta la narración, se ubica a lo político como una cuestión integral de la vida cotidiana de los pobladores y a estos como parte de una experiencia de larga data. Es decir, en Ramona se representa y reconoce al sujeto poblador ligado a la tradición obrera.

Junto al reconocimiento de la política y lo político como central para la vida de la población y de los sujetos populares urbanos, la política aparece asociada al trabajo cultural, cuestión que también remite a los orígenes del movimiento popular en Chile. Se hace una referencia en general positiva a los políticos "profesionales", como Héctor, que representa el estereotipo del "cuadro" dedicado por entero a la militancia. El personaje encarna la figura del 
activista o agitador, pero desde una óptica positiva. Así, a través del personaje de Héctor, Ramona muestra una vinculación orgánica de los "políticos" con el movimiento social; incluso, cuando se nombra a los "parlamentarios", aunque aparecen como una entidad abstracta y distante, pueden ser considerados aliados apoyando y protegiendo a las tomas de los desalojos policiales.

Desde una lectura marxista-leninista, de hecho, Héctor simboliza la "vanguardia" y, con ello, el personaje encarna una discusión histórica en la Izquierda, a saber: cuál es (o debe ser) la relación entre lo social y lo político, vinculación que, en la época de movilizaciones y transformaciones sociales que Ramona retrata, recobró actualidad y vigencia. Junto a Héctor, y en oposición al liderazgo que él encarna, emerge otro tipo de cuadro dirigente (Nelson), que cuestiona el liderazgo más bien moderado y pragmático de Héctor y propone un curso de acción más directo y voluntarista. En esta tensión y representaciones distintas de los cuadros políticos populares de base, la serie parece retratar, aunque quizás de manera relativamente estereotipada, la emergencia del Movimiento de Izquierda Revolucionario (MIR) que en esos años irrumpe en el escenario político para disputarle al Partido Comunista (PC) la conducción del movimiento popular chileno.

De igual forma, Ramona retrata la acción de una serie de sujetos adscritos a otros sectores sociales distintos a los de la toma en ejercicio de labores voluntarias (la doctora, Soledad; los estudiantes que colaboran en la toma). La realización de "trabajos voluntarios", uno de cuyos componentes principales eran los "operativos de salud", constituían, de hecho, mecanismos de conexión solidaria entre sectores sociales distintos.

\section{De los indicadores del mundo de referencia en Ramona}

Ramona ancla su acción y está ambientada en 1967. La producción reconstruye cuidadosamente la época y, con ello, un mundo y una historia verosímil, movilizando un conjunto de datos, eventos, prácticas y artefactos como claves de la época. Entre estas huellas - materiales, simbólicas, identitariasdestacan el proceso de la Reforma Agraria, la muerte del Che Guevara en Bolivia, la aparición de la revista Paula, los anticonceptivos orales y, sobre todo, ciertas afirmaciones que, por su simbolismo, remiten a la elección presidencial de 1970: "en dos años más llegará el futuro", dice un personaje.

En el caso de la Reforma Agraria, los ecos al mundo de referencia están en el primer episodio: Las hermanas Ramona y Helga van a pedir emplearse "aunque sea por un tiempo" con la dueña de una casa patronal. Las hermanas le 
explican que quieren reunir dinero para mudarse a Santiago. "Suerte", les dice la patrona mientras empaca una serie de objetos que denotan riqueza material y tradición. "Porque acá, trabajo no hay". La patrona pasa de la piedad a la indignación: "Me pregunto para qué (me piden ayuda) si seguramente ustedes van a terminar siendo las dueñas de todo esto. Vayan a pedirle trabajo a la gente de la CORA (Corporación de Reforma Agraria). Vayan a pedirle a los demócrata cristianos que ahora piensan que pueden regalar la tierra ajena".

Con una carta de recomendación de la empleada del fundo para presentar como referencia en la capital, las hermanas emprenden camino y son ayudadas por campesinos en el pick up de un camión del que cuelga un lienzo que identifica a la "Confederación Sindical Campesina Ranquil". Efectivamente, a raíz de la promulgación de la Ley de Sindicalización Campesina, junto a la Ley de Reforma Agraria, en 1967, se crearon y promovieron sindicatos campesinos que se agruparon en tres confederaciones, de distinto signo ideológico, entre la que se contaba la Confederación de Campesinos e Indígenas Ranquil, ligada al PC.

La relación que se establece entre la narración en pantalla con su mundo y época de referencia es más estrecha en relación con la toma de lo que sería luego la población La Victoria, en 1957, con la secuencia del incendio y la necesidad de tomarse otro terreno, como ocurrió efectivamente en la toma que luego sería la población Herminda de La Victoria, en 1967, en Barrancas (hoy, comuna de Cerro Navia). Esa toma de terrenos fue duramente reprimida, los pobladores resistieron el cerco policial e intento de desalojo durante tres días e, incluso, murió una niña de pocos meses de edad, llamada Herminda, de quien la población tomó su nombre.

\section{De la intertextualidad audiovisual en Ramona}

En la construcción de la serie es innegable la influencia de la cinematografía de realizadores latinoamericanos como Fernando Birri, Jorge Sanjinés, Santiago Álvarez, entre otros, que durante los años 1960 abordaron problemas sociales y de desarrollo. La visualidad de la serie rinde homenaje a la cinematografia latinoamericana durante la segunda mitad del siglo XX vinculada al realismo social y a la influencia del cine documental, en tanto cine de "hechostestimonios, o abordamiento directo de la realidad (...) un cine de dato y prueba irrefutable" (Paranaguá 469). Por ejemplo, las imágenes de archivo de un tren como un elemento que simboliza a la vez el desarrollo y la migración del campo a la ciudad, se utiliza para construir la secuencia en la que Ramona y su hermana llegan a Santiago. 
Las imágenes de la serie hacen referencia "a esta doctrina cinematográfica [del documental universitario] de preferencia por lo interválico" (Corro et al. 8). Producciones audiovisuales que tenían como ejes temáticos problemas sociales, las organizaciones políticas populares, las condiciones de vida de mineros y campesinos, la falta de vivienda, el alcoholismo y los abortos clandestinos. Ramona incorpora ciertas imágenes de archivo de documentales universitarios de la época y los utiliza como imágenes de "efecto-archivo" (Baron), insertas en la ficción utilizando la misma tonalidad -imágenes en blanco y negro- y una composición similar. De esta forma otorga un efecto de continuidad entre ambas imágenes que resaltan la estética de realidad que evoca la serie. ${ }^{11}$ Dado que los documentales usados fueron filmados originalmente en blanco y negro, el recurso de "efecto-archivo" implica que los personajes ficcionales "transiten" al color de la actualidad, como si "vinieran" de ese pasado.

Este mecanismo, además, permite poner en movimiento un sentido común audiovisual, definido como un conjunto de convenciones compartidas, tanto por los espectadores como por los realizadores, expresadas en imágenes que resulten familiares para una memoria colectiva, como las imágenes del centro de Santiago en la década de 1960 u objetos como revistas o libros, reconocibles con cierta facilidad, conectando con un pasado que se identifica en tanto pasado compartido.

Una obra audiovisual no es entendible en toda su significación desde su pura inmanencia. El sentido que vehicula no empieza ni termina en sí mismo $\mathrm{y}$, por lo tanto, no parece conveniente su estudio aislado, sino que, más bien, demanda emplazar su análisis en la perspectiva que abre la noción de discurso social de Verón, que señala que el sentido al que apunta el discurso se articula con otros discursos, de otros medios y de otros ámbitos de la sociedad. Las imágenes, los conceptos, las figuras retóricas, los sonidos y los colores, circulan por ellos, configurando un ambiente mediático, penetrante y envolvente (siguiendo libremente a McLuhan).

11 La serie incluye imágenes de obras como: Las Callampas (1958), del Instituto Fílmico de la Pontificia Universidad Católica de Chile, Caritas Chile y el Hogar de Cristo. Es un cortometraje de 19 minutos, dirigido por Rafael Sánchez, sobre los orígenes de la población La Victoria; Fragmentos de Diálogo de la calle con la Universidad (1963), cortometraje de 10 minutos realizado por el Cine Experimental de la Universidad de Chile, y de Herminda de la Victoria (1969), cortometraje documental de 22 minutos sobre la toma del mismo nombre, del Cine Experimental y dirigido por Douglas Hübner. 


\section{PALABRAS FinAleS}

Debido al Bicentenario de la Independencia, la televisión abierta produjo un conjunto de series televisivas basadas en eventos o personajes reales o, bien, ambientadas en distintos momentos de la historia chilena. Esta tendencia en la producción y circulación de discursos audiovisuales, en general en horario prime, permitió apreciar a la televisión operando de manera significativa en la (re)escritura y (re)construcción cotidiana de la realidad nacional, especialmente en los procesos de elaboración de una memoria en la perspectiva de la comunidad imaginada (Anderson).

Para Buonano, la ficción televisiva nos habla a nosotros y de nosotros, recogiendo y reelaborando los temas e intereses elementales y básicos de la vida cotidiana: el bien y el mal, el amor y el odio, la familia, la amistad, la violencia, la justicia, la enfermedad y la salud, la felicidad y las desgracias, los sueños y el miedo. Para ello, opera sobre la base de géneros y formatos conocidos en las tradiciones literaria, cinematográfica y mediática, en general.

La televisión se instala, así, como un "centro de producción de memoria", a partir de la verosimilitud alcanzada gracias a aspectos como la dirección artística, los personajes y tramas, la dramatización y, sobre todo, la individualización de los conflictos o procesos históricos (Antezana y Mateos).

Ramona tiene como tema central la marginalidad. El tipo de seres humanos que transitan y habitan en él, el tipo de relaciones, trayectorias y decisiones vitales, los entornos y escenarios en que transcurren y operan estos personajes con sus relaciones y trayectorias y mucho más, porque la marginalidad no es solo no tener casa. La serie se instala en fenómenos sociales estructurales que persisten pues no son de fácil resolución: la migración campo-ciudad, la industrialización, la modernización y el problema de la vivienda como una cuestión central, en un marco mayor que es el de la marginalidad.

La serie tiene enorme vigencia desde el lugar y momento de su lectura, en particular en relación a la revuelta popular de octubre de 2019. La pobreza, la marginalidad, la desigualdad, la injusticia, la discriminación como mecanismos persistentes de funcionamiento y organización social, y no como meros problemas individuales, hermanan a Ramona y el momento insurrecto de este siglo XXI. La marginalidad está ahí y es vivida; nunca se fue del todo a pesar de ciertos espejismos de modernidad y modernización.

Andrés Wood y la producción visibiliza y representa, a través de la serie, la marginalidad durante un periodo específico, previo a la Unidad Popular; periodo en que se gesta un proyecto político que, sabemos, quedará trunco. De ahí cierta mirada nostálgica de la serie, pues exhibe una sociedad que se dirigía hacia otro 
estado, pero que no se materializó, y las promesas de dicho proyecto, no se cumplieron. Ramona es, entonces, un registro utópico de un proyecto frustrado y que la serie materializa bajo una mirada algo ingenua y, a la vez, esperanzada. Es un proyecto limpio, que pretendía construir un mundo nuevo, con un orden y en un lugar y espacio nuevos. Las secuencias finales donde los personajes organizan el terreno tomado y proyectan sus futuras viviendas son, audiovisual y simbólicamente, luminosas.

Ramona ilustra narrativa y audiovisualmente dicho proyecto social y político en el momento de su gestación y maduración. A diferencia de otras lecturas, la de Wood y compañía incorpora un elemento relevante y que lo distingue: lo colectivo. En otras palabras, el retrato, ciertamente nostálgico, de Ramona representa en imágenes un proyecto que no es solamente político y circunscrito al sistema jurídico político del Estado-Nación, sino que es un proyecto radicalmente social: grupos sociales en movimiento y que colisionan. Wood representa esa lucha de clases.

\section{REFERENCIAS BIBLIOGRÁFICAS}

Anderson, Benedict. Comunidades imaginadas. Reflexiones sobre el origen y la difusión del nacionalismo. Fondo de Cultura Económica, 2000.

Antezana, Lorena y Mateos, Javier. "Construcción de memoria: la Dictadura a través de la ficción televisiva chilena", Historia Crítica, no. 66, 2016, pp. 109-128. https://doi.org/10.7440/histcrit66.2017.06

Baron, Jaimie. The Archive Effect: Found Footage and the Audiovisual Experience of History. Routledge, 2014.

Buonano, Milly. El drama televisivo. Identidad y contenidos sociales. Gedisa Editorial, 1999.

Corro, Pablo, et al. Teorías del Cine Documental Chileno 1957-1973. Pontificia Universidad Católica de Chile, 2007.

De Ramón, Armando. Santiago de Chile. Editorial Sudamericana, 2000.

Espinoza, Vicente. Historia social de la acción colectiva urbana: los pobladores de Santiago, 1957-1987. EURE, 1998.

Garcés, Mario. Crisis social y motines populares en el 1900. Ediciones ECO/ Documentas, 1991.

-----. Tomando su sitio. El movimiento de pobladores de Santiago, 1957-1970. LOM Ediciones, 2002.

Gramsci, Antonio. El materialismo histórico y la filosofía de Benedetto Croce. Juan Pablos Editor, 1975. 
Guzmán, Juan Andrés y Marcela Ramos. La Guerra y la Paz Ciudadana. LOM Ediciones, 2000.

Hurtado, María de la Luz. Historia de la TV en Chile (1958 - 1973). DocumentasCéneca, 1988.

King, John. El Carrete mágico. Una historia del cine latinoamericano. TM Editores, 1994.

Latcham, Ricardo, et al. El Criollismo. Editorial Universitaria, 1956.

Larraín, Jorge. Identidad chilena. LOM Ediciones, 2001.

Lefebvre, Henri. La vida cotidiana en el mundo moderno. Alianza Editorial, 1956.

Martín-Barbero, Jesús. De los medios a las mediaciones. Editorial Gustavo Gili, 1987.

Martín-Barbero, J. y S. Muñoz. Televisión y melodrama. Tercer Mundo Editores, 1992.

Mattelart, Michelle. "Apuntes sobre lo moderno: una manera de leer la revista femenina ilustrada". Ideología y medios de comunicación, compilado por M. Garretón, Amorrortu Editores, 1973, pp. 140-169.

McLuhan, Marshall y Quentin Fiore. El medio es el masaje. Un inventario de efectos. Paidós, 1988.

Memoria Chilena. "Minisitio: Manuel Rojas (1896-1973)"

(http://www.memoriachilena.gob.cl/602/w3-article-3592.html) y

"Minisitio: Literatura de bajos fondos"

(http://www.memoriachilena.gob.cl/602/w3-article-3556.html).

Montalva, Pía. Morir un poco. Moda y sociedad en Chile 1960-1976. Catalonia, 2015.

Ortiz, Renato. Mundialización y Cultura. Alianza Editorial, 1997.

Paranaguá, Paulo Antonio (ed.). Cine documental en América Latina. Cátedra, 2003.

Pinto, Julio y Gabriel Salazar. Historia Contemporánea de Chile: Actores, identidad y movimiento, Volumen II. LOM Ediciones, 1999.

Rodrigo-Alsina, Miquel. La construcción de la noticia. Paidós, 1996.

Romero, José Luis. Latinoamérica. Las ciudades y las ideas. Siglo XXI Editores, 2007.

Romero, Luis Alberto. ¿Qué hacer con los pobres? Elite y sectores populares en Santiago de Chile, 1840-1895. Editorial Sudamericana, 1997.

Salazar, Gabriel. Violencia política popular en las "Grandes Alamedas", Santiago de Chile 1947-1987. Ediciones SUR, 1990.

-----. Labradores, peones y proletarios. LOM Ediciones, 2000. 
Salinas, Claudio y Stange, Hans. "Este cine chacotero... Impostura y desproblematización en las representaciones del sujeto popular en el cine chileno 1997-2005". Cuadernos de Trabajo, Instituto de Comunicación e Imagen, Universidad de Chile, 2006.

Salinas, Claudio, Stange, et al. “¿Géneros o estrategias? Discursos históricos y cinematográficos en el cine chileno de ficción”, Aisthesis, no. 63, 2018, pp. 9-25. https://doi.org/10.7764/aisth.63.1

Salinas, M., et al. El Chile de Juan Verdejo. El humor político de Topaze 19311970. Editorial Universidad de Santiago, 2011.

Santa Cruz A., Eduardo. Las telenovelas puertas adentro. El discurso social de la telenovela chilena. LOM Ediciones, 2001.

-----. La prensa chilena en el siglo XIX. Patricios, letrados, burgueses y plebeyos. Editorial Universitaria, 2010.

-----. "Cine y sociedad en Chile en la década de 1940". La mirada obediente. Historia nacional en el cine chileno, editado por C. Salinas y H. Stange, Editorial Universitaria, 2017, pp. 57-78.

Silva Castro, Raúl. Alberto Blest Gana. Editorial Zigzag, 1955.

-----. Baldomero Lillo (1867-1923). Nascimento, 1968.

Subercaseaux, Bernardo. Historia de las ideas y de la cultura en Chile. Nacionalismo y Cultura. Tomo IV. Editorial Universitaria, 2007.

Verón, Eliseo. "Esquema para el análisis de la mediatización", Revista DIÁLOGOS, no. 48, 1997, pp. 10-17.

Vial Correa, Gonzalo. Historia de Chile (1891-1973). La sociedad chilena en el cambio de siglo (1891-1920). Volumen I, Tomo II. Editorial Santillana del Pacífico, 1984. 